\title{
Article
}

\section{Switchable catalysts for chemical CO2 recycling: A step forward in the methanation and reverse water-gas shift reactions}

Estelle le Sache, Laura Pastor-Pérez, Bradley J Haycock, Juan Jose Villora-Picó, Antonio Sepúlveda-Escribano, and Tomas Ramirez Reina

ACS Sustainable Chem. Eng., Just Accepted Manuscript • DOI: 10.1021/

acssuschemeng.0c00551 - Publication Date (Web): 06 Mar 2020

Downloaded from pubs.acs.org on March 10, 2020

\section{Just Accepted}

"Just Accepted" manuscripts have been peer-reviewed and accepted for publication. They are posted online prior to technical editing, formatting for publication and author proofing. The American Chemical Society provides "Just Accepted" as a service to the research community to expedite the dissemination of scientific material as soon as possible after acceptance. "Just Accepted" manuscripts appear in full in PDF format accompanied by an HTML abstract. "Just Accepted" manuscripts have been fully peer reviewed, but should not be considered the official version of record. They are citable by the Digital Object Identifier (DOI®). "Just Accepted" is an optional service offered to authors. Therefore, the "Just Accepted" Web site may not include all articles that will be published in the journal. After a manuscript is technically edited and formatted, it will be removed from the "Just Accepted" Web site and published as an ASAP article. Note that technical editing may introduce minor changes to the manuscript text and/or graphics which could affect content, and all legal disclaimers and ethical guidelines that apply to the journal pertain. ACS cannot be held responsible for errors or consequences arising from the use of information contained in these "Just Accepted" manuscripts. 


\title{
Switchable catalysts for chemical $\mathrm{CO}_{2}$ recycling: A step forward in the methanation and reverse water-gas shift reactions
}

\author{
Estelle le Saché, ${ }^{a}$ Laura Pastor-Pérez, ${ }^{* a}$ Bradley J. Haycock, ${ }^{a}$ Juan José Villora-Picó, ${ }^{\mathrm{b}}$ Antonio \\ Sepúlveda-Escribano ${ }^{b}$ and Tomas Ramirez Reina ${ }^{a}$ \\ a Department of Chemical and Process Engineering Department, University of Surrey, Guildford, \\ GU2 7XH United Kingdom \\ b Laboratorio de Materiales Avanzados, Departamento de Química Inorgánica Instituto \\ Universitario de Materiales de Alicante, Universidad de Alicante, Alicante, E-03080 Spain. \\ *Corresponding author and lead contact: l.pastorperez@surrey.ac.uk
}

\begin{abstract}
Advanced catalytic technologies are crucial to enable the transition towards a low-carbon industry with minimised $\mathrm{CO}_{2}$ emissions. This paper showcases the application of highly effective Ru-promoted $\mathrm{Ni}$-based catalysts for gas-phase $\mathrm{CO}_{2}$ upgrading: $\mathrm{CO}_{2}$-methanation and reverse water-gas shift. The addition of small amounts of Ru results in a remarkable enhancement of $\mathrm{CO}_{2}$ conversion and selectivity. The bimetallic Ru-Ni catalyst displays greater metallic dispersion and tuned electronic properties that benefit the $\mathrm{CO}_{2}$ conversion. Furthermore, the Ru-Ni catalyst displays outstanding stability for long term runs - a mandatory requisite for its implementation in actual $\mathrm{CO}_{2}$ conversion units. The singularity of our advanced catalyst lays on its capacity to work effectively for both the $\mathrm{CO}_{2}$ methanation and the reverse water-gas shift, allowing endproduct flexibility by adjusting the reactor temperature. Such versatility opens a big range of possibilities to adapt this technology in heavy carbon industries whose net $\mathrm{CO}_{2}$ emissions represent a big share in the global greenhouse gases emissions.
\end{abstract}

Keywords: Switchable catalysts, $\mathrm{CO}_{2}$ recycling, RWGS, methanation, RuNi catalyst

\section{Introduction}

Climate change is a major issue facing the world today, and how the world tackles this phenomenon will have a significant effect on society. It is known that climate change is rapidly accelerated with the continuous release of carbon dioxide $\left(\mathrm{CO}_{2}\right)$ into the atmosphere. ${ }^{1}$ Therefore, it is vital that the release of $\mathrm{CO}_{2}$ is prevented wherever feasible. $\mathrm{CO}_{2}$ utilisation is a very attractive solution to this problem, as it prevents the release of this detrimental greenhouse gas, while also converting the $\mathrm{CO}_{2}$ into useful fuels and chemicals and, as a result, addressing the issue of resource depletion as well. Conventional carbon capture techniques, such as carbon capture and storage (CCS), tackle the emission problem to an extend but does not provide a sustainable solution to the climate crisis. ${ }^{2}$ There are various methods for utilising $\mathrm{CO}_{2}$, however this paper will focus on the conversion of $\mathrm{CO}_{2}$ to synthetic natural gas (SNG) and carbon 
monoxide (CO) via the methanation of $\mathrm{CO}_{2}$ reaction (Eq. (1)) and the reverse water-gas shift (rWGS) reaction (Eq. (2)), respectively.

$$
\begin{aligned}
& \mathrm{CO}_{2}+4 \mathrm{H}_{2} \leftrightharpoons \mathrm{CH}_{4}+2 \mathrm{H}_{2} \mathrm{O}, \Delta \mathrm{H}^{\circ}{ }_{298 \mathrm{~K}}=-165.0 \mathrm{~kJ} / \mathrm{mol} \\
& \mathrm{CO}_{2}+\mathrm{H}_{2} \leftrightharpoons \mathrm{CO}+\mathrm{H}_{2} \mathrm{O}, \Delta \mathrm{H}^{\circ}{ }_{298 \mathrm{~K}}=+41.0 \mathrm{~kJ} / \mathrm{mol}
\end{aligned}
$$

Burning natural gas is considered relatively clean when compared to burning other fossil fuels, due to the relatively reduced $\mathrm{CO}_{2}$ emissions. ${ }^{3}$ Natural gas also has excellent operational flexibility, allowing it to be paired with renewable energy sources to achieve the electricity demand at peak times. ${ }^{4}$ The rWGS reaction is usually used as a starting point for many industrial applications, conventionally being used in conjunction with the Fischer-Tropsch (FT) process to produce hydrocarbon fuels. ${ }^{5}$ Both natural gas and $\mathrm{CO}$ are also used extensively in the steel industry. The natural gas is used in the furnace for scrap melting ${ }^{6}$ and $\mathrm{CO}$ is used to reduce the metal ores. ${ }^{7}$ The steel industry also currently produces an alarming amount of $\mathrm{CO}_{2}-$ over 2 billion tonnes per year. Therefore, $\mathrm{CO}_{2}$ valorisation deserves further investigation to potentially solve this global crisis.

Since the methanation of $\mathrm{CO}_{2}$ is exothermic and the rWGS reaction is endothermic, the product selectivity obtained can be altered depending on the reaction temperature set, according to Le Chatelier's principle. This is extremely beneficial to certain industrial applications that require both natural gas and $\mathrm{CO}$ for their processes, as an increase of the reaction temperature will produce more $\mathrm{CO}$ and a decrease of temperature will produce more natural gas, meaning the product composition may be controlled depending on which component is in higher demand.

Indeed, there are also several competing reactions that may occur with the reactants and products from the methanation of $\mathrm{CO}_{2}$ and the rWGS reaction, ${ }^{2}$ resulting in a lower product selectivity than desired.

$$
\begin{aligned}
& \mathrm{CO}_{2}+2 \mathrm{H}_{2} \leftrightharpoons \mathrm{C}+2 \mathrm{H}_{2} \mathrm{O}, \Delta \mathrm{H}^{\circ}{ }_{298 \mathrm{~K}}=+90.1 \mathrm{~kJ} / \mathrm{mol} \\
& \mathrm{CO}_{2}+\mathrm{CH}_{4} \leftrightharpoons 2 \mathrm{CO}+2 \mathrm{H}_{2}, \Delta \mathrm{H}^{\circ}{ }_{298 \mathrm{~K}}=+247.3 \mathrm{~kJ} / \mathrm{mol}
\end{aligned}
$$

With both of these reactions being endothermic, they only become prominent at higher temperatures, meaning that they only compete with the RWGS reaction, which is also conducted at high temperatures. Even then, the $\mathrm{CH}_{4}$ dry reforming reaction (Eq. (4)) produces $\mathrm{CO}$ as a product, which is the desired product when conducting the rWGS reaction, meaning that this reaction is not directly competing with it. The Bosch reaction (Eq. (3)) however, is directly competing with the RWGS reaction, as it is taking the $\mathrm{CO}_{2}$ reactant and producing solid carbon as a waste product.

Fig. 1 summarises the idea of integrating the methanation and rWGS processes with heavy $\mathrm{CO}_{2}$-producing processes which are used in many industries. Assuming that renewable hydrogen or any other source of hydrogen on the plant is present, $\mathrm{CO}_{2}$ methanation and the rWGS reaction are viable routes to prevent the release of $\mathrm{CO}_{2}$ produced and to recycle the products from these reactions to manufacture further useful products, while reducing the carbon tax leading to an increased profitability. Along with the obvious economic advantages, the approach schematised in Fig. 1 also represents a step ahead towards more sustainable industrial processes. 


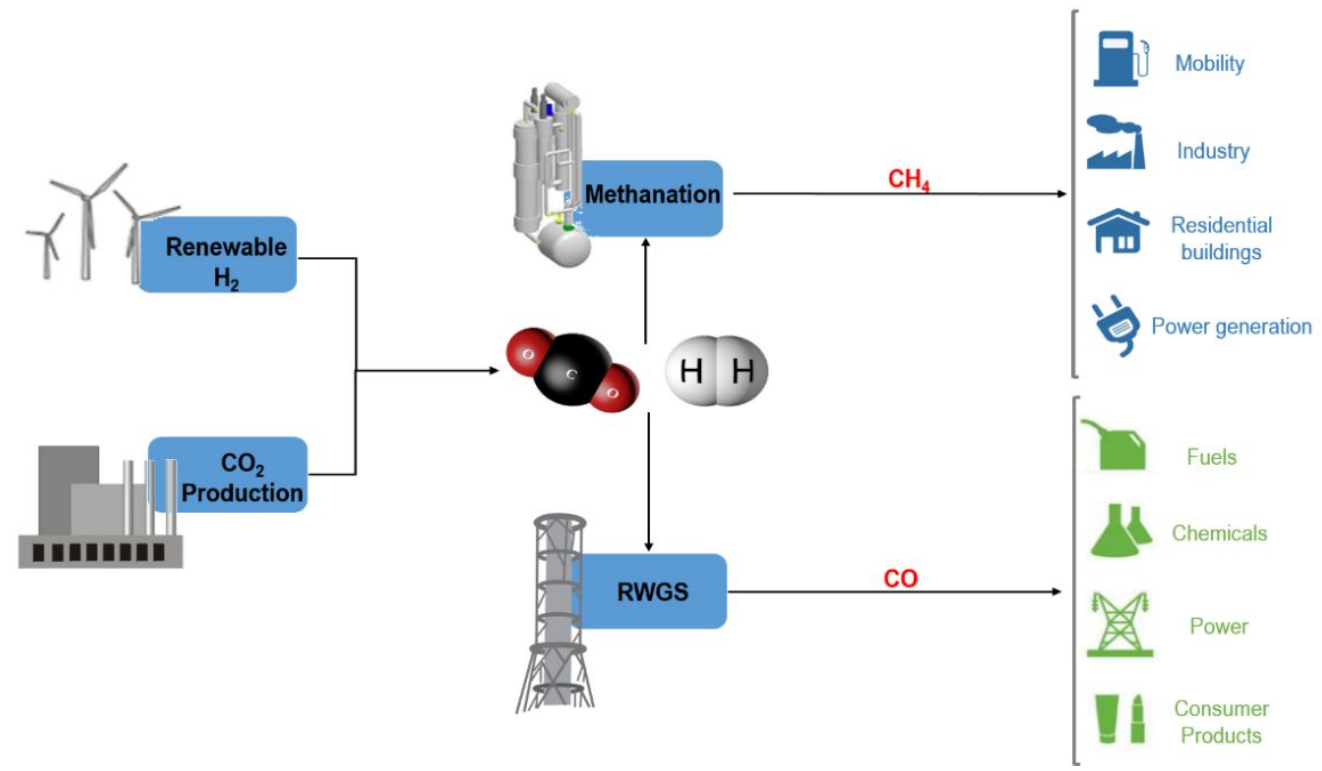

Fig. 1 Simplified schematic of the methanation and rWGS processes integrated with heavy $\mathrm{CO}_{2}$-producing industries.

Due to the high stability of $\mathrm{CO}_{2}$ molecules, catalysts need to be employed for both the methanation of $\mathrm{CO}_{2}$ and the rWGS reaction to enhance reaction kinetics. Commonly, Ni-based catalysts are utilised for both reactions,,$^{2,8-11}$ due to the high catalytic activity and low cost of $\mathrm{Ni}$. In addition, various supports have also been used in conjunction with $\mathrm{Ni}$ for both reactions, including $\mathrm{CeO}_{2}{ }^{12-15}, \mathrm{ZrO}_{2}{ }^{16,17}, \mathrm{TiO}_{2}{ }^{18,19}, \mathrm{SiO}_{2}{ }^{20,21}$ and $\mathrm{Al}_{2} \mathrm{O}_{3}{ }^{5,8,22-24}$. $\mathrm{CeO}_{2}$ is an exceptional choice as support for $\mathrm{CO}_{2}$ valorisation catalysts, due to the ability of $\mathrm{CeO}_{2}$ to vary the oxygen concentration without changing phase, resulting in a large amount of oxygen vacancies required for the reactions. ${ }^{12} \mathrm{ZrO}_{2}$ is another excellent choice of support because of its acid/base features and $\mathrm{CO}_{2}$ adsorption capabilities. ${ }^{2}$ Combining $\mathrm{CeO}_{2}$ and $\mathrm{ZrO}_{2}$ to formulate a ceria-zirconia solid solution $\mathrm{Ce}_{0.5} \mathrm{Zr}_{0.5} \mathrm{O}_{2}$ ( $\mathrm{CeZr}$ ) support, enhances the performance of the support, as beneficial properties from both $\mathrm{CeO}_{2}$ and $\mathrm{ZrO}_{2}$ may be obtained. $\mathrm{CeZr}$ solid solution has been intensively developed as automotive exhaust catalysts. It possesses advanced redox properties, excellent thermal stability, and resistance to sintering. ${ }^{25}$ Specifically, the insertion of $\mathrm{ZrO}_{2}$ into the cubic lattice of $\mathrm{CeO}_{2}$ increases thermal stability while the distortion of the $\mathrm{O}^{2-}$ sublattice allows higher oxygen mobility. Redox properties are therefore no longer confined in the surface but extended to the bulk. ${ }^{26}$ In fact, oxygen bulk diffusion is approximately two orders of magnitude higher for ceria-zirconia than for ceria. ${ }^{27}$

Noble metals such as $\mathrm{Pt}, \mathrm{Rh}$, and Ru have been successfully used in hydrogenation reactions and display $\mathrm{CO}_{2}$ conversions close to equilibrium. Their coking resistance is superior to transition metals, but their high cost and low availability constitute a remarkable limitation. Ru is the most economical noble metal and benefits from a large number of oxidation states that exhibit high electron transfer, which is highly valuable for $\mathrm{CO}_{2}$ hydrogeneration. Promoting $\mathrm{Ni}$ with Ru allows a compromise on cost while benefiting from a synergistic relationship between different metals. ${ }^{15}$ Pairing Ni with Ru led to an increased Ni dispersion in a study from Crisafulli et al. ${ }^{28}$ and 
enhanced nickel reducibility in a study from Valdes-Martinez et al. ${ }^{29}$, which may be related to hydrogen dissociation on $\mathrm{Ru}^{0}$ and a spillover effect.

Fe-based catalysts are heavily used in commercial high temperature WGS process and hence, are of interest for the rWGS reaction. Their activity is related with the easy formation of the $\mathrm{Fe}^{3+} \leftrightarrow \mathrm{Fe}^{2+}$ redox couple. Ru-Fe bimetallic catalysts were found to be very active towards rWGS; in particular, Fe addition improved $\mathrm{CO}$ selectivity at high temperature, benefiting from the synergistic effect between the $\mathrm{Ru}$ and $\mathrm{Fe}$ metals. ${ }^{15}$ Yang et al. ${ }^{8}$ attributed the higher activity/selectivity of a $\mathrm{Ni}-\mathrm{Fe}$ catalyst to an electronic enrichment of the $\mathrm{Ni}$ surface atoms due to the $\mathrm{FeO}_{x}-\mathrm{Ni}$ interaction. The higher electronic density of the NiFe catalyst facilitates $\mathrm{CO}_{2}$ adsorption, which is the rate-limiting step of rWGS. In addition, FeOx enhanced Ni dispersion on the surface, which also helps to deliver higher activity in the reactions.

The addition of iron to a Ni-alumina catalyst was reported to significantly improve the activity for the methanation of $\mathrm{CO}_{2}$ as well, compared to other transition metals. ${ }^{30}$ The rates of $\mathrm{CO}_{2}$ conversion and methane formed were also significantly enhanced by the substitution of 10 and $25 \%$ of $\mathrm{Ni}$ with $\mathrm{Fe}$ in $\mathrm{Ni}-\mathrm{Fe}$ system, due to the formation of a NiFe alloy. ${ }^{31}$

However, no investigations have yet been performed which compare Ni supported on CeZr catalysts promoted with $\mathrm{Fe}$ and $\mathrm{Ru}$ as potential catalysts for both the methanation of $\mathrm{CO}_{2}$ and the rWGS reactions. Following this, a series of $\mathrm{Ni}$ supported on $\mathrm{Ce}_{0.5} \mathrm{Zr}_{0.5} \mathrm{O}_{2}$ catalysts have been prepared and promoted with $\mathrm{Fe}$ and $\mathrm{Ru}$. These catalysts were prepared to test their performance with respect to both the methanation of $\mathrm{CO}_{2}$ and the rWGS reactions. Herein, the spirit of this work is to find a switchable catalyst that is highly effective for both reactions, which may constitute a realistic solution towards the decarbonisation of the heavy carbon industry.

\section{Experimental}

Catalyst Synthesis

The materials were prepared by sequential wet impregnation. First, the necessary amount of $\mathrm{Ni}\left(\mathrm{NO}_{3}\right)_{2} \cdot 6 \mathrm{H}_{2} \mathrm{O}$ (Merck) was dissolved in ethanol and added to a commercial CeZr support (Daiichi Kigenso Kagaku Kogyo Co.) to obtain $15 \mathrm{wt} . \%$ Ni. The resulting solution was evaporated under reduced pressure and dried overnight at $80^{\circ} \mathrm{C}$. Following this, the material was calcined for three hours at $500^{\circ} \mathrm{C}$.

Sequentially, promoters were added following the same method, using $\mathrm{Fe}\left(\mathrm{NO}_{3}\right)_{3} \cdot 9 \mathrm{H}_{2} \mathrm{O}$ (Merck) and a $\mathrm{Ru}(\mathrm{NO})\left(\mathrm{NO}_{3}\right) \mathrm{x} \cdot(\mathrm{OH}) \mathrm{y}$ solution (Alfa Aesar). Overall, four catalysts were synthetized: a monometallic Ni/CeZr, two bimetallic FeNi/CeZr and RuNi/CeZr containing 1 wt.\% of promoter and a trimetallic RuFeNi/CeZr containing $0.5 \mathrm{wt} . \%$ of each promoter.

\section{Catalyst Characterisation}

X-Ray diffraction (XRD) analysis was performed on the fresh, reduced and spent catalyst samples using an $X^{\prime}$ Pert Powder instrument from PANalytical. The diffraction patterns were recorded over a $2 \theta$ range of $10-80^{\circ}$. A step size and time step of $0.05^{\circ}$ and $240 \mathrm{~s}$ were used 
respectively. The diffraction patterns were recorded at $30 \mathrm{~mA}$ and $40 \mathrm{kV}$, using $\mathrm{Cu} \mathrm{K} \alpha$ radiation $(\lambda=0.154 \mathrm{~nm})$. The average crystallite size was then calculated using the Scherrer equation.

$\mathrm{H}_{2}$-TPR experiments were carried out in a continuous fixed bed quartz reactor using a $10 \%$ $\mathrm{H}_{2} / \mathrm{Ar}$ gas stream flowing at $50 \mathrm{~mL} \mathrm{~min}{ }^{-1} .50 \mathrm{mg}$ of each catalyst were loaded into the reactor and the gas stream was passed through, while heating the catalyst up to $900{ }^{\circ} \mathrm{C}$ from room temperature, using a temperature ramp of $10{ }^{\circ} \mathrm{C} \mathrm{min}^{-1}$. The hydrogen consumption was then observed using an on-line mass spectrometer (Pfeiffer, OmniStar GSD 301).

The textural properties of each catalyst were obtained using nitrogen adsorption-desorption isotherms associated with a Micrometrics Tristar 22 instrument at $-196{ }^{\circ} \mathrm{C}$. Before the measurements were taken, each sample was degassed at $250^{\circ} \mathrm{C}$ under vacuum for 4 hours. The specific surface area of the samples was then calculated using the Brunauer-Emmett-Teller (BET) method and the pore volume and pore size distribution were evaluated using the Barrett-JoynerHalenda (BJH) method.

Raman spectroscopy was conducted using a Thermo Scientific DXR Raman Microscope utilising a green laser $(\lambda=532 \mathrm{~nm}$, maximum power $10 \mathrm{~mW})$, which has a spot diameter of 0.7 $\mu \mathrm{m}$ and a pinhole aperture of $50 \mu \mathrm{m}$. Additionally, a diffraction grating of 900 grooves $\mathrm{mm}^{-1}$ was used, along with a CCD detector and a 50x objective.

X-Ray photoelectron spectroscopy (XPS) analyses were performed with a VGMicrotechMultilab 3000 spectrometer equipped with a hemispherical electron analyser and a $\mathrm{Mg}-\mathrm{K} \alpha(\mathrm{h}=1253.6 \mathrm{eV} ; 1 \mathrm{eV}=1.6302 \cdot 10-19 \mathrm{~J})$ 300-W X-ray source. The powder samples were pressed into small Inox cylinders. Before recording the spectra, the samples were maintained in the analysis chamber until a residual pressure of ca. 5.10-7 $\mathrm{N} \mathrm{m}^{-2}$ was reached. The spectra were collected at a pass energy of $50 \mathrm{eV}$. The intensities were estimated by calculating the integral of each peak, after subtracting the S-shaped background, and by fitting the experimental curve to a combination of Lorentzian (30\%) and Gaussian (70\%) lines. The binding energy (BE) of the C 1s peak at $284.9 \mathrm{eV}$ was taken as an internal standard. The accuracy of the BE values is $\pm 0.2 \mathrm{eV}$. The samples were reduced ex-situ at the reaction temperature $\left(850^{\circ} \mathrm{C}\right)$, and conserved in octane before the analysis

\section{Catalytic Behaviour}

For the catalytic analysis, each catalyst was placed inside a vertical fixed bed quartz reactor. The product stream was analysed using an ABB AO2020 Advanced Optima Process Gas Analyser.

Prior to any catalytic measurements, $250 \mathrm{mg}$ of catalyst were reduced in situ at $850{ }^{\circ} \mathrm{C}$ for one hour in a $10 \% \mathrm{H}_{2} / \mathrm{N}_{2}$ stream with a total flow rate of $100 \mathrm{~mL} \mathrm{~min}^{-1}$. Post reduction, temperature screening experiment was conducted for each sample. The reactants were held at a constant weight hourly space velocity (WHSV) of $24000 \mathrm{~mL} \mathrm{~g}^{-1} \mathrm{~h}^{-1}$ with a $\mathrm{H}_{2} / \mathrm{CO}_{2}$ ratio of 4:1. The reaction temperature was varied from $200^{\circ} \mathrm{C}$ to $850^{\circ} \mathrm{C}$, moving in $50^{\circ} \mathrm{C}$ intervals, with each reaction temperature being held for 20 minutes. The carbon balance was closed within $5 \%$ error for each test.

Each stability test was conducted for a total of 100 hours, changing the reaction temperature every 24 hours between $350{ }^{\circ} \mathrm{C}$ (methanation temperature) and $700{ }^{\circ} \mathrm{C}$ (rWGS temperature). 
The catalytic activity was investigated using $\mathrm{CO}_{2}$ conversion (Eq. (5)), $\mathrm{CH}_{4}$ selectivity (Eq. (6)) and CO selectivity (Eq. (7)).

$\mathrm{CO}_{2}$ conversion $(\%)=\left(\left[\mathrm{CO}_{2}\right]_{\text {in }}-\left[\mathrm{CO}_{2}\right]_{\text {out }}\right) /\left(\left[\mathrm{CO}_{2}\right]_{\text {in }}\right) \times 100$

$\mathrm{CH}_{4}$ selectivity $(\%)=\left(\left[\mathrm{CH}_{4}\right]_{\text {out }}\right) /\left(\left[\mathrm{CO}_{2}\right]_{\text {in }}-\left[\mathrm{CO}_{2}\right]_{\text {out }}\right) \times 100$

CO selectivity $(\%)=\left([\mathrm{CO}]_{\text {out }}\right) /\left(\left[\mathrm{CO}_{2}\right]_{\text {in }}-\left[\mathrm{CO}_{2}\right]_{\text {out }}\right) \times 100$

where $\left[\mathrm{CO}_{2}\right]_{\text {in }}$ is the initial concentration of $\mathrm{CO}_{2}$ in the reactant mixture and $\left[\mathrm{CO}_{2}\right]_{\text {out }},\left[\mathrm{CH}_{4}\right]_{\text {out }}$ and $[\mathrm{CO}]_{\text {out }}$ are the outlet concentrations in the product stream of $\mathrm{CO}_{2}, \mathrm{CH}_{4}$ and $\mathrm{CO}$ respectively.

The thermodynamic equilibrium for $\mathrm{CO}_{2}$ conversion was established across the entire temperature range to give a better understanding of the experimental results. The equilibrium $\mathrm{CO}_{2}$ conversion was obtained using ChemStations' ChemCad software, utilising a Gibbs reactor. The Soave-Redlich-Kwong equation of state was used for the simulation and the feed material flows were implemented to mimic the material flows that are intended for experimentation. The results of the simulation are shown in the catalyst performance plots.

\section{Results and Discussion}

Catalyst Characterisation Results

\section{XRD}

The XRD patterns for each calcined sample are shown in Fig. S1. Each sample shows diffraction peaks at $2 \theta=37.2^{\circ}, 43.3^{\circ}$ and $62.9^{\circ}$, which correspond to the NiO fcc phase (JCPDS 00-047-1049), while also containing peaks at $2 \theta=29.2^{\circ}, 34.0^{\circ}, 48.9^{\circ}, 58.0^{\circ}$ and $60.8^{\circ}$, which all correspond to a single tetragonal crystal structure of $\mathrm{Ce}_{0.5} \mathrm{Zr}_{0.5} \mathrm{O}_{2}$ (JCPDS 00-038-1436). No peaks related to $\mathrm{RuO}_{\mathrm{x}}$ or $\mathrm{Fe}_{\mathrm{x}} \mathrm{O}_{\mathrm{y}}$ were observed due to the very small quantities in the samples.

Additional information may be extracted from the XRD patterns of the reduced samples shown in Fig. S2. The XRD patterns show the reduction of the $\mathrm{NiO}$ to $\mathrm{Ni}^{0}$ with the appearance of peaks at $2 \theta=44.4^{\circ}$ and $51.7^{\circ}$, characteristic of metallic Ni (JCPDS 04-0850). NiO is still present in all reduced samples, as can be seen in the XPS section, although it is not evident in the XRD profiles. The crystallite size of the Ni particles was evaluated using the Scherrer equation and results are presented in Table 1. Overall, the addition of promoters decreases the Ni crystallite size and hence improves $\mathrm{Ni}$ dispersion. ${ }^{8,28}$ In particular, RuNi/CeZr presents the smallest $\mathrm{Ni}$ particles, in good agreement with the enhanced activity performance of this catalyst, later discussed.

Table 1. Textural properties of all samples and CeZr support. 


\section{$\mathrm{H}_{2}$-TPR}

In hydrogenation reactions, such as the methanation of $\mathrm{CO}_{2}$ and the rWGS reaction, redox properties are very relevant. $\mathrm{H}_{2}$-TPR measurements were performed to determine the reducibility of each catalyst. The profiles of each sample are shown in Fig. 2.

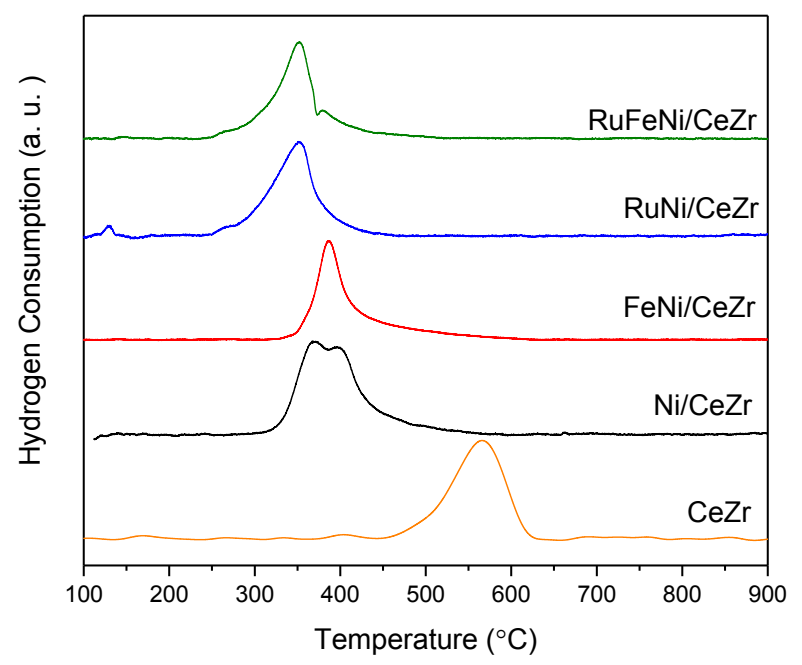

Fig. $2 \mathrm{H}_{2}$-TPR profiles for each catalyst.

The CeZr support presents the typical large reduction peak at $570{ }^{\circ} \mathrm{C}$ of ceria-zirconia-based oxides corresponding to the reduction of $\mathrm{Ce}^{4+}$ to $\mathrm{Ce}^{3+}$. In comparison with the metal supported catalysts, the hydrogen consumption of the support was negligible, and the normalised profiles are shown for better visibility. The monometallic Ni/CeZr sample presents two reduction processes. The first event occurring at $370{ }^{\circ} \mathrm{C}$ is due to the reduction of $\mathrm{Ni}^{2+}$ to $\mathrm{Ni}^{0}$, whereas the second event at $400{ }^{\circ} \mathrm{C}$ is attributed to the reduction of the surface oxygen in $\mathrm{Ce}_{0.5} \mathrm{Zr}_{0.5} \mathrm{O}_{2}$ and $\mathrm{Ni}^{2+}$ strongly interacting with CeZr support. ${ }^{25,32}$ The introduction of $\mathrm{Fe}$ in the formulation led to a more homogeneous reduction zone at $386^{\circ} \mathrm{C}$ where $\mathrm{Fe}_{x} \mathrm{O}_{y}, \mathrm{NiO}$ and $\mathrm{Ce}_{0.5} \mathrm{Zr}_{0.5} \mathrm{O}_{2}$ oxygen species are jointly reduced. ${ }^{2}$ Usually Fe-based catalysts present two reduction zones (or a broader band at higher temperatures), which can be attributed to the reduction of the iron oxides occurring 
over two separate stages. The presence of only one reduction zone is indicative of the high $\mathrm{Ni}$ Fe-Support interaction.

The addition of $\mathrm{Ru}$, on the other hand, introduced two reduction processes. The peak at 130 ${ }^{\circ} \mathrm{C}$ is due to the reduction of $\mathrm{Ru}^{4+}$ to metallic $\mathrm{Ru}$, and the peak at $265^{\circ} \mathrm{C}$ could be related to the reduction of $\mathrm{Ni}-\mathrm{Ru}$ and $\mathrm{Ni}-\mathrm{Ce}$ species. ${ }^{29}$ Additionally, in Ru-containing samples, the reduction peak of $\mathrm{NiO}$ shifted towards lower temperatures indicating that the Ni reducibility was enhanced due to the presence of Ru. Hydrogen adsorbs dissociatively on $\mathrm{Ru}$ and $\mathrm{H}$ atoms spillover to the near $\mathrm{NiO}$, enabling its reduction. This also indicates that $\mathrm{Ru}$ is in intimate contact with $\mathrm{NiO}^{29,33}$ Finally, the TPR profile of the trimetallic catalyst is very similar to RuNi/CeZr, while presenting a small peak at $380^{\circ} \mathrm{C}$ associated with the reduction of $\mathrm{Fe}_{x} \mathrm{O}_{y}$ species. ${ }^{34}$

\section{Textural Properties}

The textural properties of each catalyst sample and the CeZr support are shown in Table 1, and the corresponding isotherms are presented in Fig. S3. The textural properties of the catalysts are governed by the CeZr support. All materials show type IV isotherms with their corresponding H4-type hysteresis loop at relatively high pressures, which indicates that each sample and the support is of a mesoporous nature, according to the IUPAC classification. This can be confirmed by the results shown for the textural properties in Table 1.

The specific surface areas, as well as the total pore volume of the catalysts, slightly decrease with the impregnation of metals on the support. This is due to the metal covering the pores of the CeZr support.

\section{XPS}

In contrast, while XRD is a bulk technique in which we could only see the major crystalline species of $\mathrm{Ni}$ (metallic in the reduced samples) and the support, XPS is able to measure elements from the topmost layers of 3-5 $\mathrm{nm}$ thick slabs of the surface species, which is essential to discern the chemical status of our Ru and Fe promoters and Ni active species.

The Ni $2 p_{3 / 2}$ spectrum of all reduced samples can be observed in Fig. 3 . In order to reproduce as far as possible the catalysts status before the reaction runs, the samples were pre-reduced $850^{\circ} \mathrm{C}$ before the XPS analysis. The spectra show that only a part of Ni was in the metallic state (band around $851-853 \mathrm{eV}$ ) and different nickel species (bands around at 854 and $856 \mathrm{eV}$ are ascribed to $\mathrm{Ni}^{2+}$ ) co-exist in the reduced catalysts, as it can be seen in the complex $\mathrm{Ni} 2 \mathrm{p}_{3 / 2}$ spectra (Fig. 3). 


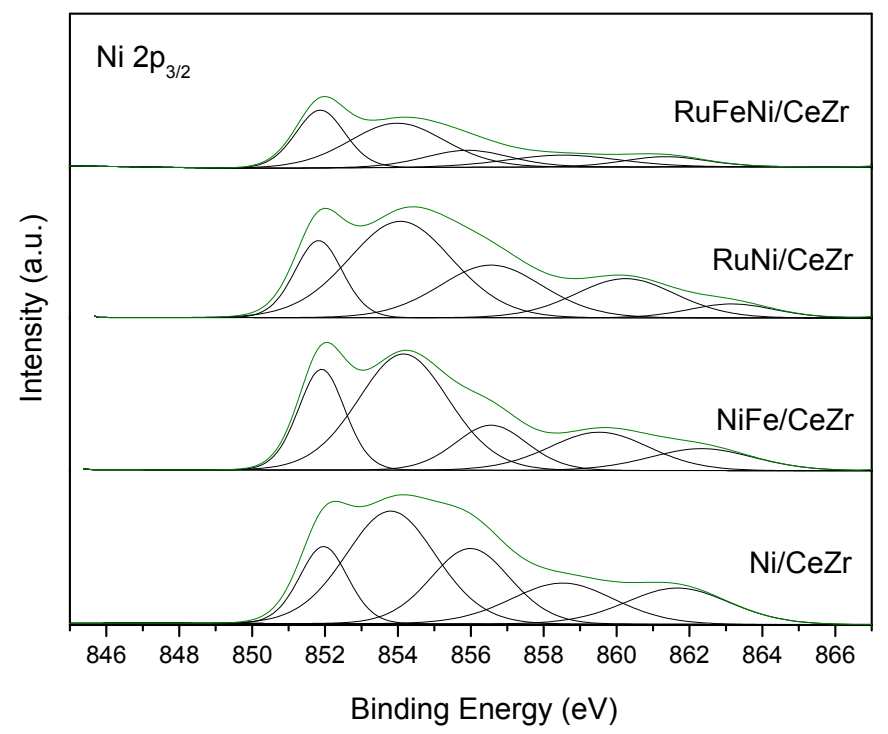

Fig. 3 XPS spectra of $\mathrm{Ni} 2 \mathrm{p}_{3 / 2}$ region for all reduced samples.

Table 2 Binding energies of the $\mathrm{Ni} 2 \mathrm{p}_{3 / 2}, \mathrm{Fe} 2 \mathrm{p}_{3 / 2}$ and Ru $3 \mathrm{p}_{3 / 2}$ levels for the reduced catalysts and $\mathrm{Ni} /$ Support and $\mathrm{Ni}^{\circ} / \mathrm{Ni}_{\text {total }}$ atomic ratios.

\begin{tabular}{|c|c|c|c|c|c|c|c|c|c|}
\hline \multirow{2}{*}{ Catalysts } & \multicolumn{2}{|c|}{$\mathrm{Ni} 2 p_{3 / 2}$} & \multicolumn{3}{|c|}{$\mathrm{Fe} 2 \mathrm{p}_{3 / 2}$} & \multicolumn{2}{|c|}{$\operatorname{Ru} 3 p_{3 / 2}$} & \multirow{2}{*}{$\mathrm{Ni} /$ Support } & \multirow{2}{*}{$\mathrm{Ni}^{0} / \mathrm{Ni}_{\text {total }}$} \\
\hline & $\mathrm{Ni}$ & $\mathrm{Ni}^{2+}$ & $\mathrm{Fe}^{0}$ & $\mathrm{Fe}^{2+}$ & $\mathrm{Fe}^{3+}$ & $\mathbf{R u}^{0}$ & $\mathrm{Ru}^{2+}$ & & \\
\hline $\mathrm{Ni} / \mathrm{CeZr}$ & 852.0 & $\begin{array}{l}853.8- \\
855.9\end{array}$ & -- & -- & -- & -- & -- & 0.032 & 0.132 \\
\hline FeNi/CeZr & 851.9 & $\begin{array}{c}854.1- \\
856.6\end{array}$ & 709.1 & 711.7 & 713.6 & -- & -- & 0.044 & 0.190 \\
\hline RuNi/CeZr & 851.8 & $\begin{array}{l}854.1- \\
856.6\end{array}$ & -- & -- & -- & 459.7 & 462.7 & 0.252 & 0.150 \\
\hline RuFeNi/CeZr & 851.8 & $\begin{array}{l}853.9- \\
855.9\end{array}$ & -- & 711.7 & 715.0 & 461.1 & -- & 0.218 & 0.362 \\
\hline
\end{tabular}

For the Fe-, Ru- and FeRu-promoted samples, a slight shift towards lower Ni B.E. values was obtained (see Table 2). This indicates that $\mathrm{Fe}$ and Ru appear to enhance Ni reducibility, thus favouring metallic nickel formation, as corroborated by the $\mathrm{Ni}^{0} / \mathrm{Ni}_{\text {total }}$ ratio present in Table 2 .

The presence of $\mathrm{Fe}$ as a promoter (and the formation of additional oxygen vacancies) improves the reduction of $\mathrm{NiO}$ as well as slightly enhances the $\mathrm{Ni}$ dispersion, as can be deduced from the $\mathrm{Ni} /$ support ratio increase.

The latter fact is more notorious for the Ru-Ni bimetallic catalyst, in which the nickel dispersion is remarkably boosted by the Ru promoter. This high dispersion was also maintained 
in the Ru-Fe-Ni sample. In addition, in this sample, the increasing Ni reducibility was even more notorious due to the presence of both Fe and Ru promoters.

For a better understanding about the different interactions between metals, Ru $3 p_{3 / 2}$ and Fe $2 p_{3 / 2}$ binding energies are also reported in Table 2 . In the bimetallic catalysts, RuNi/CeZr and $\mathrm{FeNi} / \mathrm{CeZr}$, both metal and oxide states are present in the XPS of Ru and Fe promoters. Nevertheless, for the trimetallic catalyst, RuFeNi/CeZr, the presence of Fe improved both $\mathrm{Ni}$ and Ru reduction, as it has been discussed already, showing only one Ru peak at $461.07 \mathrm{eV}$ ascribed to metallic Ru. ${ }^{35}$

In summary from the characterisation results, our catalysts are complex samples with metallic $\mathrm{Ni}$ as dominant active phase, showing different levels of electronic interactions with the promoters, Ru and Fe. The redox and the electronic properties of our multicomponent catalysts are linked to the metal-support and metal-promoter interactions, which can influence the catalytic behaviour. All of them show similar textural properties, and the bimetallic $\mathrm{Ni}$-Ru system displays the smallest Ni particle size and then the greatest Ni dispersion

\section{Catalyst Performance}

\section{Temperature Screening}

The catalysts performance in terms of $\mathrm{CO}_{2}$ conversion as a function of temperature are shown in Fig. 4 whereas product selectivities are shown in Fig. 5. The promoters' effect on the catalytic activity is very clear. Although at temperatures above $700{ }^{\circ} \mathrm{C}$, all catalysts reach equilibrium conversion and no effect are noticeable, great differences can be witnessed at lower temperatures. Below $700{ }^{\circ} \mathrm{C}$, the addition of $\mathrm{Fe}$ to the $\mathrm{Ni} / \mathrm{CeZr}$ catalyst inhibits the $\mathrm{CO}_{2}$ conversion. However, the Fe-promoted sample show higher selectivity towards CO over the entire temperature range. According to DFT simulations, Fe alone and Fe-containing bimetallic particles have the lowest activation energy for $\mathrm{CO}_{2}$ dissociation, and are therefore most favoured to dissociate $\mathrm{CO}_{2}$ to $\mathrm{CO}$ and $\mathrm{O}^{36}$ The presence of $\mathrm{Fe}$ oxides decreases the affinity of the surface for $\mathrm{CO}$, leading to $\mathrm{CO}$ desorption instead of subsequent methanation. ${ }^{34}$

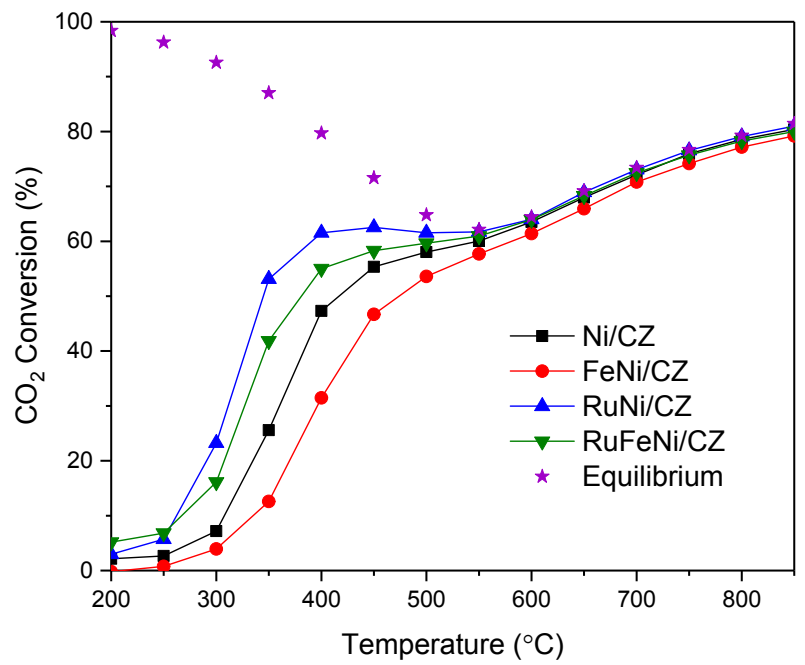

Fig. $4 \mathrm{CO}_{2}$ conversion for all catalysts as a function of temperature. 
The addition of $\mathrm{Ru}$, however, greatly improves the $\mathrm{CO}_{2}$ conversion of the catalyst, especially in the methanation region from 300 to $450{ }^{\circ} \mathrm{C}$ since ruthenium is more effective in $\mathrm{H}_{2}$ dissociation/adsorption than nickel, which is another fundamental step of reaction mechanism. ${ }^{37}$ Additionally, the Ru bimetallic catalyst is highly selective towards $\mathrm{CH}_{4}$ at low temperature. When both $\mathrm{Fe}$ and $\mathrm{Ru}$ are added to the $\mathrm{Ni} / \mathrm{CeZr}$ catalyst, the opposite effects of each promoter are combined. The trimetallic catalyst shows greater conversion than the unpromoted catalyst due to the Ru promoting effect, yet lesser than the Ru bimetallic catalyst due Fe inhibiting effect. In terms of selectivity, Fe enhanced CO selectivity at low temperatures. The catalysts performance rank in the following order for both methanation and rWGS reaction: $\mathrm{RuNi} / \mathrm{CeZr}>\mathrm{Ni} / \mathrm{CeZr}>\mathrm{RuFeNi} / \mathrm{CeZr}>\mathrm{FeNi} / \mathrm{CeZr}$.

Based on the temperature screening experiments, it was deemed that the RuNi/CeZr catalyst overall showed the best results, especially when the combination of both reactions is envisaged as the main target. This result is in good agreement with the characterisation analysis. Indeed, the RuNi catalyst presents the lowest particle size. The promoting effect of Ru increased the reducibility of $\mathrm{Ni}$ and improved its dispersion as confirmed by TPR and XPS.

Fig. 5 a) $\mathrm{CH}_{4}$ selectivity and b) $\mathrm{CO}$ selectivity of all catalysts with respect to temperature
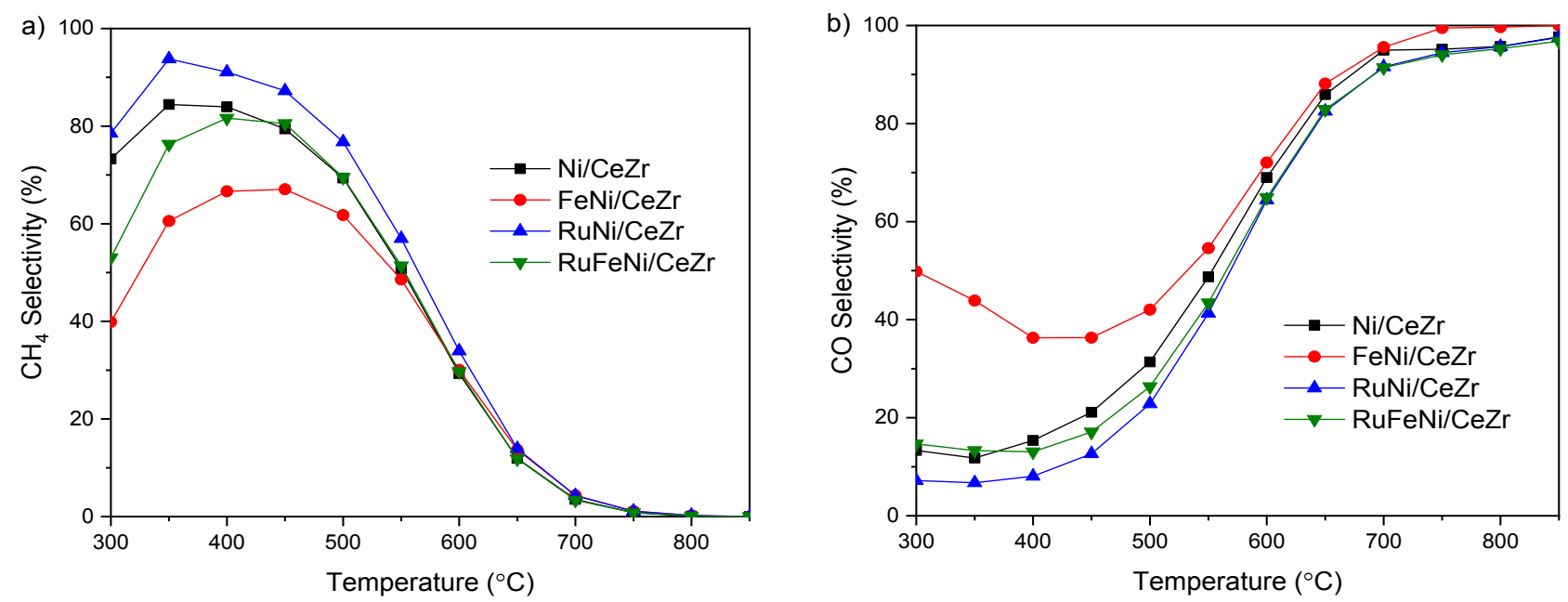

Performance of our catalyst was compared to similar compositions from the literature, which are presented in Table 3. Overall, in rWGS conditions, the RuNi/CeZr and FeNi/CeZr catalysts reached equilibrium conversion and range within the highest selectivities. However in methanation conditions, our catalysts present moderate conversions compared to other $\mathrm{Ni}$ based catalyst, although presenting equivalent selectivity towards methane when promoted with Ru. In contrast, none of the catalysts cited were tested for both reaction conditions showcasing the originality of our versatile catalysts.

Table 3 Catalytic performance comparison with $\mathrm{Fe}, \mathrm{Ni}$ and $\mathrm{Ru}$ based catalysts reported in literature.

\begin{tabular}{ccccccc} 
Material & $\begin{array}{c}\text { WHSV } \\
\left(\mathrm{mL} \mathrm{g}^{-1} \mathrm{~h}^{-1}\right)\end{array}$ & $\begin{array}{c}\text { Temperature } \\
\left({ }^{\circ} \mathrm{C}\right)\end{array}$ & $\begin{array}{c}\text { Feed } \\
\mathrm{H}_{2} / \mathrm{CO}_{2} \\
(\mathbf{v} / \mathbf{v})\end{array}$ & $\begin{array}{c}\mathrm{CO}_{2} \text { conversion } \\
(\%)\end{array}$ & $\begin{array}{c}\text { Selectivity } \\
(\%)\end{array}$ & Ref \\
\hline $\mathrm{Fe} / \mathrm{CeO}_{2}-\mathrm{Al}_{2} \mathrm{O}_{3}$ & 30000 & 700 & $4 / 1$ & 69 & 100 & 38
\end{tabular}




\begin{tabular}{|c|c|c|c|c|c|c|}
\hline $\mathrm{FeMo} / \mathrm{CeO}_{2}-\mathrm{Al}_{2} \mathrm{O}_{3}$ & 30000 & 700 & $4 / 1$ & 54 & 100 & \\
\hline $\mathrm{FeNi} / \mathrm{CeO}_{2}-\mathrm{Al}_{2} \mathrm{O}_{3}$ & 30000 & 700 & $4 / 1$ & 73 & 95 & \\
\hline $\mathrm{Fe} / \gamma-\mathrm{Al}_{2} \mathrm{O}_{3}$ & 12500 & 700 & $4 / 1$ & 70 & 100 & 5 \\
\hline $\mathrm{FeCu} / \gamma-\mathrm{Al}_{2} \mathrm{O}_{3}$ & 12500 & 700 & $4 / 1$ & 72 & 100 & \\
\hline $\mathrm{FeCs} / \gamma-\mathrm{Al}_{2} \mathrm{O}_{3}$ & 12500 & 700 & $4 / 1$ & 70 & 100 & \\
\hline $\mathrm{Ni} / \gamma-\mathrm{Al}_{2} \mathrm{O}_{3}$ & 30000 & 700 & $4 / 1$ & 56 & 85 & 8 \\
\hline $\mathrm{Ni} / \mathrm{CeO}_{2}-\mathrm{Al}_{2} \mathrm{O}_{3}$ & 30000 & 700 & $4 / 1$ & 68 & 92 & \\
\hline $\mathrm{NiFe} / \mathrm{CeO}_{2}-\mathrm{Al}_{2} \mathrm{O}_{3}$ & 30000 & 700 & $4 / 1$ & 72 & 92 & \\
\hline $\mathrm{NiCr} / \mathrm{CeO}_{2}-\mathrm{Al}_{2} \mathrm{O}_{3}$ & 30000 & 700 & $4 / 1$ & 60 & 75 & \\
\hline RuNi/CeZr & 24000 & 700 & $4 / 1$ & 72 & 91 & This work \\
\hline FeNi/CeZr & 24000 & 700 & $4 / 1$ & 71 & 91 & This work \\
\hline $\mathrm{Ni} / \mathrm{CeZr}$ & 12500 & 350 & $4 / 1$ & 79 & 85 & 2 \\
\hline $\mathrm{NiFe} / \mathrm{CeZr}$ & 12500 & 350 & $4 / 1$ & 68 & 78 & \\
\hline $\mathrm{NiCo} / \mathrm{CeZr}$ & 12500 & 350 & $4 / 1$ & 86 & 93 & \\
\hline $\mathrm{Ni} / \mathrm{CeO}_{2}$ & $10,000 h^{-1}$ & 350 & $4 / 1$ & 87 & 100 & 39 \\
\hline $\mathrm{Ni} / \mathrm{MgO}$ & $10,000 h^{-1}$ & 350 & $4 / 1$ & 28 & 100 & \\
\hline $\mathrm{Ni} / \mathrm{TiO}_{2}$ & $10,000 h^{-1}$ & 350 & $4 / 1$ & 30 & 100 & \\
\hline $\mathrm{Ni} / \alpha-\mathrm{Al}_{2} \mathrm{O}_{3}$ & $10,000 h^{-1}$ & 350 & $4 / 1$ & 58 & 97 & \\
\hline $1 \% \mathrm{Ru} / \gamma-\mathrm{Al}_{2} \mathrm{O}_{3}$ & $10,000 h^{-1}$ & 350 & $5 / 1$ & 30 & - & 37 \\
\hline $4 \% \mathrm{Ru} / \gamma-\mathrm{Al}_{2} \mathrm{O}_{3}$ & $10,000 h^{-1}$ & 350 & $5 / 1$ & 81 & 99 & \\
\hline $15 \% \mathrm{Ni} / \nu-\mathrm{Al}_{2} \mathrm{O}_{3}$ & $10,000 \mathrm{~h}^{-1}$ & 350 & $5 / 1$ & 63 & - & \\
\hline $12 \% \mathrm{Ni} / \nu-\mathrm{Al}_{2} \mathrm{O}_{3}$ & $10,000 h^{-1}$ & 350 & $5 / 1$ & 58 & 98 & \\
\hline RuNi/CeZr & 24000 & 350 & $4 / 1$ & 53 & 93 & This work \\
\hline $\mathrm{FeNi} / \mathrm{CeZr}$ & 24000 & 350 & $4 / 1$ & 13 & 60 & This work \\
\hline
\end{tabular}




\section{Stability test}

Conducting a stability test is essential before any considerations can be made to upscale the catalyst for realistic applications. A stable catalyst is economically crucial since it guaranties the quality of the products as well as reduced maintenance operational costs. Therefore, the most performant catalyst, RuNi/CeZr, was submitted to a time dependent stability test of 100 hours. The stability test was conducted over four 24 hours cycles at different temperatures. The temperature was switched from $350{ }^{\circ} \mathrm{C}$ to $700{ }^{\circ} \mathrm{C}$ to mimic a change in operating conditions between a methanation process and a rWGS unit. The effect of starting temperature was studied as well as the ability of the catalyst to recover its performance after a change of cycle.
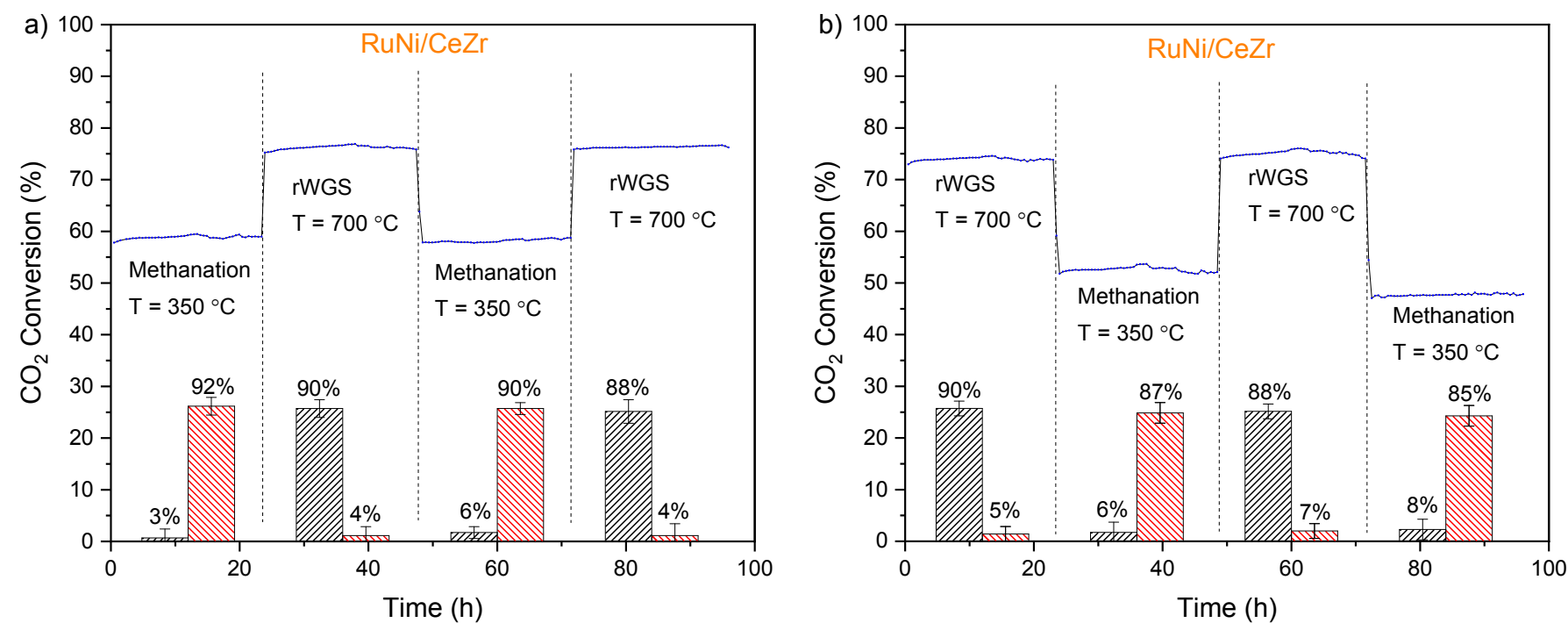

Fig. 6 Stability test for the RuNi/CeZr catalyst, varying temperature between $350{ }^{\circ} \mathrm{C}$ and 700 ${ }^{\circ} \mathrm{C}$, starting with a) the methanation cycle and b) the RWGS cycle. Product selectivity is represented as column, black for $\mathrm{CO}$ and red for $\mathrm{CH}_{4}$.

The conversion of $\mathrm{CO}_{2}$ and associated products selectivity recorded during both stability tests can be viewed in Fig. 6 . The results clearly show the catalyst is extremely stable, maintaining a $\mathrm{CO}_{2}$ conversion of around $55 \%$ in the methanation zone, while maintaining a $\mathrm{CO}_{2}$ conversion of around $75 \%$ in the rWGS zone. It appears that the time on stream did not affect the performance of the catalyst, since the conversion is steady, however the change in cycle did influence the catalyst activity and selectivity. The change in cycle did not affect the rWGS activity since the catalyst was able to recover its $75 \% \mathrm{CO}_{2}$ conversion in both tests. However, a slight decrease in CO selectivity can be witness after the second rWGS cycle. On the other hand, the activity of the catalyst for methanation is affected by the high temperature cycles. The $\mathrm{CO}_{2}$ conversion during methanation in Fig. $6 \mathrm{~b}$, is $5 \%$ lower when preceded by a rWGS cycle. The rWGS cycles are performed above the Tammann temperature of $\mathrm{Ni}$, while the methanation cycles are taking place, below. Hence the rWGS cycle is not affected by the methanation cycle but some metallic sintering may occur due to the rWGS cycles affecting the performance of the catalyst at low temperature. Indeed, as shown in Fig. 7, the XRD patterns of the post-stability samples corroborate the sintering phenomenon to some extent. More specifically, the crystallite size was estimated at $36.1 \mathrm{~nm}$ for the first stability test and $37.7 \mathrm{~nm}$ for the second, against $33.6 \mathrm{~nm}$ before reaction. 
Along with sintering, carbon deposition is a major culprit in heterogeneous catalysis resulting in catalysts deactivation. Raman spectroscopy (spectrum showed in Fig. S4) was conducted to assess any potential solid carbon formation. The Raman spectra show the typical modes associated with tetragonal $\mathrm{Ce}_{0.5} \mathrm{Zr}_{0.5} \mathrm{O}_{2}$ solid solution. ${ }^{40}$ Typical $\mathrm{D}$ band and $\mathrm{G}$ band of carbon occur at $1350 \mathrm{~cm}^{-1}$ and $1585 \mathrm{~cm}^{-1}$, and none of them can be seen on the obtained Raman spectra. Therefore, no deactivation due to carbon deposition occurred on the catalyst during the stability test. This is in fact in fair agreement with the excellent stability displayed by our bimetallic Ru$\mathrm{Ni}$ catalysts, which can be considered a highly effective and versatile system for gas phase $\mathrm{CO}_{2}$ upgrading.

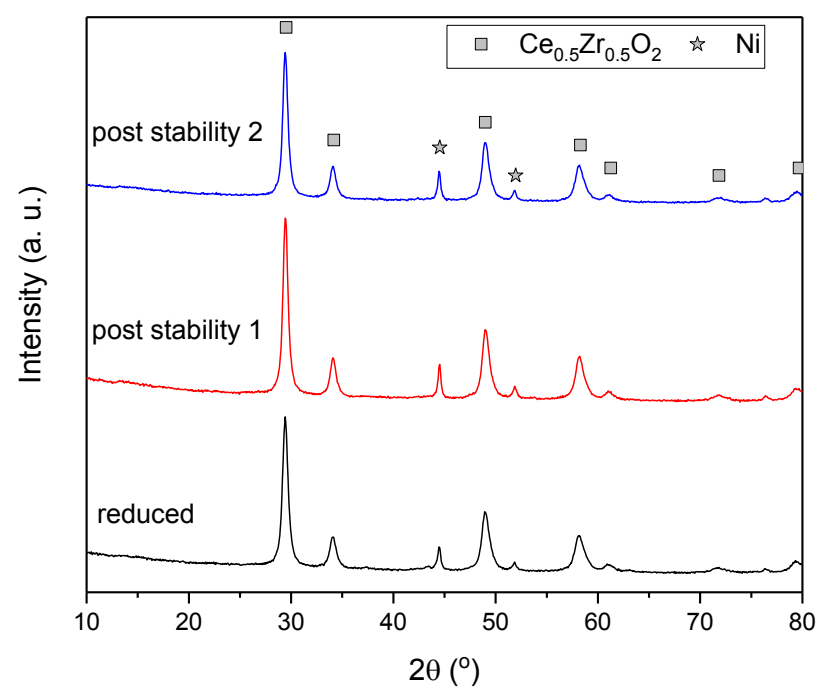

Fig. 7 XRD patterns of the RuNi/CeZr catalyst post reduction and post stability test.

\section{Conclusions}

Heterogeneous catalysis will play a major role in the transition towards a low carbon society, and this work represents a successful example of how advanced catalysts can impact the reduction of $\mathrm{CO}_{2}$ emissions. Herein, we have developed very effective catalysts for chemical $\mathrm{CO}_{2}$ recycling via rWGS and $\mathrm{CO}_{2}$-methanation - both gas phase processes which can be implemented to minimise greenhouse gas emissions in heavy carbon industries. Our catalysts are based on Fe- and Ru-promoted Ni supported on CeZr oxide. In particular, the bimetallic Ru-Ni catalyst is an excellent system for both reactions.

The addition of Ru enhances $\mathrm{Ni}$ reducibility and leads to greater Ni dispersion on the catalyst surface, thus promoting the catalytic performance. Furthermore, the intrinsic activity of Ru for $\mathrm{CO}_{2}$ hydrogenations helps to improve the overall activity/selectivity. Along with its high $\mathrm{CO}_{2}$ conversion capacity and outstanding selectivity, the catalyst is very stable for long term operations - an indispensable requisite for realistic applications. Its robustness is attributed to the suppression of solid carbon formation, which is a major culprit for benchmark catalysts typically used in these reactions.

The uniqueness of our material relies on its versatility to be used in both $\mathrm{CO}_{2}$-methanation and rWGS. In other words, we have developed a flexible catalyst which delivers synthetic natural gas or carbon monoxide by simply adjusting the reactor temperature. Such a switchable material 
opens many opportunities for major $\mathrm{CO}_{2}$ emitters such as refineries, steel and cement making plants where both $\mathrm{CO}$ and $\mathrm{CH}_{4}$ are useful chemicals and $\mathrm{CO}_{2}$ emissions are a major problem. Although up scaling of these materials and their testing under realistic industrial environment is beyond the scope of this paper, the findings presenting here represent a step-ahead to enable the urgently needed industrial decarbonisation.

\title{
ASSOCIATED CONTENT
}

\section{Supporting Information. Supporting info Switchable catalysts-ACS.docx}

XRD patterns of the calcined samples (Fig. S1), XRD patterns of the reduced samples (Fig. S2), $\mathrm{N}_{2}$ adsorption-desorption isotherms at -196 ㄷ for all catalyst and the CeZr support (Fig. S3), Raman spectrum of RuNi/CeZr after $100 \mathrm{~h}$ of stability test (Fig. S4).

\section{Author information \\ Corresponding Author *: I.pastorperez@surrey.ac.uk}

\section{Author Contributions}

The manuscript was written through contributions of all authors. All authors have given approval to the final version of the manuscript.

\section{Acknowledgements}

Financial support for this work was provided by the Department of Chemical and Process Engineering at the University of Surrey and the EPSRC grant EP/R512904/1 as well as the Royal Society Research Grant RSGR1180353. LPP acknowledges Generalitat Valenciana for her APOSTD2017 fellowship. This work was also partially sponsored by the CO2Chem through the EPSRC grant EP/P026435/1. DAIICHI KIGENSO KAGAKU KOGYO CO., LTD. is kindly acknowledged for providing the $\mathrm{Ce}_{0.5} \mathrm{Zr}_{0.5} \mathrm{O}_{2}$ support.

\begin{abstract}
Abbreviations
CCS, Carbon Capture and storage; SNG, Synthetic Natural Gas; rWGS, reverse Water Gas Shift; FT, Fischer-Tropsch; CeZr, $\mathrm{Ce} 0.5 \mathrm{Zr}_{0.5} \mathrm{O}_{2} ; \mathrm{TPR}$, Temperature Programmed Reduction.
\end{abstract}

\section{References}

1. Florides, G. A.; Christodoulides, P. Global warming and carbon dioxide through sciences. Environ. Int. 2009, 35 (2), 390-401. https://doi.org/10.1016/j.envint.2008.07.007

2. Pastor-Pérez, L.; le Saché, E.; Jones, C.; Gu, S.; Arellano-Garcia, H.; Reina, T. R. Synthetic natural gas production from $\mathrm{CO}_{2}$ over $\mathrm{Ni}-\mathrm{x} / \mathrm{CeO}_{2}-\mathrm{ZrO}_{2}(\mathrm{x}=\mathrm{Fe}, \mathrm{Co})$ catalysts: Influence of 
promoters and space velocity. Catal. Today 2017, 317, 108-113. https://doi.org/10.1016/j.cattod.2017.11.035

3. Koytsoumpa, E. I.; Karellas, S.; Kakaras, E. Modelling of Substitute Natural Gas production via combined gasification and power to fuel. Renew. Energ. 2019, 135, 1354-1370. https://doi.org/10.1016/j.renene.2018.09.064

4. Rao, A. G.; van den Oudenalder, F. S. C.; Klein, S. A. Natural gas displacement by wind curtailment utilization in combined-cycle power plants. Energy 2019, 168, 477-491. https://doi.org/10.1016/j.energy.2018.11.119

5. Pastor-Pérez, L.; Baibars, F.; le Saché, E.; Arellano-García, H.; Gu, S.; Reina, T. R. $\mathrm{CO}_{2}$ valorisation via Reverse Water-Gas Shift reaction using advanced $\mathrm{Cs}$ doped $\mathrm{Fe}-\mathrm{Cu} / \mathrm{Al}_{2} \mathrm{O}_{3}$ catalysts. J. CO2 Util. 2017, 21, 423-428. https://doi.org/10.1016/j.jcou.2017.08.009

6. Kovačič, M.; Šarler, B. Genetic programming prediction of the natural gas consumption in a steel plant. Energy 2014, 66, 273-284. https://doi.org/10.1016/j.energy.2014.02.001

7. Abu Tahari, M. N.; Salleh, F.; Tengku Saharuddin, T. S.; Dzakaria, N.; Samsuri, A.; Mohamed Hisham, M. W.; Yarmo, M. A. Influence of hydrogen and various carbon monoxide concentrations on reduction behavior of iron oxide at low temperature. Int. J. Hydrogen Energy 2018, 44 (37), 20751-20759. https://doi.org/10.1016/j.ijhydene.2018.09.186

8. Yang, L.; Pastor-Pérez, L.; Gu, S.; Sepúlveda-Escribano, A.; Reina, T. R. Highly efficient $\mathrm{Ni} / \mathrm{CeO}_{2}-\mathrm{Al}_{2} \mathrm{O}_{3}$ catalysts for $\mathrm{CO}_{2}$ upgrading via reverse water-gas shift: Effect of selected transition metal promoters. Appl. Catal. B 2018, 232, 464-471. https://doi.org/10.1016/j.apcatb.2018.03.091

9. Zhang, Z.; Tian, Y.; Zhang, L.; Hu, S.; Xiang, J.; Wang, Y.; Xu, L.; Liu, Q.; Zhang, S.; Hu, X., Impacts of nickel loading on properties, catalytic behaviors of $\mathrm{Ni} / \mathrm{Y}-\mathrm{Al}_{2} \mathrm{O}_{3}$ catalysts and the reaction intermediates formed in methanation of $\mathrm{CO}_{2}$. Int. J. Hydrogen Energy 2019, 44 (18), 9291-9306. https://doi.org/10.1016/j.ijhydene.2019.02.129

10. Rodrigues, M. T.; Zonetti, P. C.; Alves, O. C.; Sousa-Aguiar, E. F.; Borges, L. E. P.; Appel, L. G. RWGS reaction employing $\mathrm{Ni} / \mathrm{Mg}(\mathrm{Al}, \mathrm{Ni}) \mathrm{O}$ - The role of the $\mathrm{O}$ vacancies. Appl. Catal. A 2017, 543, 98-103. https://doi.org/10.1016/j.apcata.2017.06.026

11. Liang, C.; Hu, X.; Wei, T.; Jia, P.; Zhang, Z.; Dong, D.; Zhang, S.; Liu, Q.; Hu, G. Methanation of $\mathrm{CO}_{2}$ over $\mathrm{Ni} / \mathrm{Al}_{2} \mathrm{O}_{3}$ modified with alkaline earth metals: Impacts of oxygen vacancies on catalytic activity. Int. J. Hydrogen Energy 2019, 44 (16), 8197-8213. https://doi.org/10.1016/j.ijhydene.2019.02.014

12. Sakpal, T.; Lefferts, L. Structure-dependent activity of $\mathrm{CeO}_{2}$ supported Ru catalysts for $\mathrm{CO}_{2}$ methanation. J. Catal. 2018, 367, 171-180. https://doi.org/10.1016/j.jcat.2018.08.027

13. Le, T. A.; Kim, M. S.; Lee, S. H.; Kim, T. W.; Park, E. D. $\mathrm{CO}$ and $\mathrm{CO}_{2}$ methanation over supported $\mathrm{Ni}$ catalysts. Catal. Today 2017, 293-294, 89-96. https://doi.org/10.1016/j.cattod.2016.12.036

14. Ricca, A.; Truda, L.; Palma, V. Study of the role of chemical support and structured carrier on the $\mathrm{CO}_{2}$ methanation reaction. Chem. Eng. J. 2018, 377, 120461-12068. https://doi.org/10.1016/j.cattod.2016.12.036 
15. Panaritis, C.; Edake, M.; Couillard, M.; Einakchi, R.; Baranova, E. A. Insight towards the role of ceria-based supports for reverse water gas shift reaction over RuFe nanoparticles. J. CO2 Util. 2018, 26, 350-358. https://doi.org/10.1016/j.jcou.2018.05.024

16. Li, W.; Nie, X.; Jiang, X.; Zhang, A.; Ding, F.; Liu, M.; Liu, Z.; Guo, X.; Song, C. ZrO 2 support imparts superior activity and stability of Co catalysts for $\mathrm{CO}_{2}$ methanation. Appl. Catal. B 2018, 220, 397-408. https://doi.org/10.1016/j.apcatb.2017.08.048

17. Tao, Y.; Zhu, Y.; Liu, C.; Yue, H.; Ji, J.; Yuan, S.; Jiang, W.; Liang, B. A highly selective $\mathrm{Cr} / \mathrm{ZrO}_{2}$ catalyst for the reverse water-gas shift reaction prepared from simulated $\mathrm{Cr}$-containing wastewater by a photocatalytic deposition process with $\mathrm{ZrO}_{2}$. J. Environ. Chem. Eng. 2018, 6 (6), 6761-6770. https://doi.org/10.1016/j.jece.2018.10.043

18. Petala, A.; Panagiotopoulou, P. Methanation of $\mathrm{CO}_{2}$ over alkali-promoted $\mathrm{Ru} / \mathrm{TiO} \mathrm{O}_{2}$ catalysts: I. Effect of alkali additives on catalytic activity and selectivity. Appl. Catal. B 2018, 224, 919-927. https://doi.org/10.1016/j.apcatb.2017.11.048

19. Tada, S.; Kikuchi, R.; Wada, K.; Osada, K.; Akiyama, K.; Satokawa, S.; Kawashima, Y. Longterm durability of $\mathrm{Ni} / \mathrm{TiO}_{2}$ and $\mathrm{Ru}-\mathrm{Ni} / \mathrm{TiO}_{2}$ catalysts for selective $\mathrm{CO}$ methanation. J. Power Sources 2014, 264, 59-66. https://doi.org/10.1016/j.jpowsour.2014.04.075

20. Le, T. A.; Kim, T. W.; Lee, S. H.; Park, E. D. Effects of $\mathrm{Na}$ content in $\mathrm{Na} / \mathrm{Ni} / \mathrm{SiO}_{2}$ and $\mathrm{Na} / \mathrm{Ni} / \mathrm{CeO}_{2}$ catalysts for $\mathrm{CO}$ and $\mathrm{CO}_{2}$ methanation. Catal. Today 2018, 303, 159-167. https://doi.org/10.1016/j.cattod.2017.09.031

21. Le, T. A.; Kang, J. K.; Park, E. D. $\mathrm{CO}$ and $\mathrm{CO}_{2}$ Methanation Over Ni/SiC and Ni/SiO 2 Catalysts. Top. Catal. 2018, 61 (15), 1537-1544. https://doi.org/10.1007/s11244-018-0965-7

22. Pastor-Pérez, L.; Shah, M.; le Saché, E.; Ramirez Reina, T. Improving $\mathrm{Fe} / \mathrm{Al}_{2} \mathrm{O}_{3}$ Catalysts for the Reverse Water-Gas Shift Reaction: On the Effect of Cs as Activity/Selectivity Promoter. Catalysts 2018, 8 (12), 608. https://doi.org/10.3390/catal8120608

23. Garbarino, G.; Bellotti, D.; Riani, P.; Magistri, L.; Busca, G. Methanation of carbon dioxide on $\mathrm{Ru} / \mathrm{Al}_{2} \mathrm{O}_{3}$ and $\mathrm{Ni} / \mathrm{Al}_{2} \mathrm{O}_{3}$ catalysts at atmospheric pressure: Catalysts activation, behaviour and stability. Int. J. Hydrogen Energy 2015, 40 (30), 9171-9182. https://doi.org/10.1016/j.ijhydene.2015.05.059

24. Garbarino, G.; Riani, P.; Magistri, L.; Busca, G. A study of the methanation of carbon dioxide on $\mathrm{Ni} / \mathrm{Al}_{2} \mathrm{O}_{3}$ catalysts at atmospheric pressure. Int. J. Hydrogen Energy 2014, 39 (22), 11557-11565. https://doi.org/10.1016/j.ijhydene.2014.05.111

25. Pan, Q.; Peng, J.; Sun, T.; Gao, D.; Wang, S.; Wang, S. $\mathrm{CO}_{2}$ methanation on Ni/Ce $\mathrm{Cl}_{0.5} \mathrm{Zr}_{0.5} \mathrm{O}_{2}$ catalysts for the production of synthetic natural gas. Fuel Process. Technol. 2014, 123, 166-171. https://doi.org/10.1016/j.fuproc.2014.01.004

26. Kozlov, A. I.; Kim, D. H.; Yezerets, A.; Andersen, P.; Kung, H. H.; Kung, M. C. Effect of Preparation Method and Redox Treatment on the Reducibility and Structure of Supported CeriaZirconia Mixed Oxide. J. Catal. 2002, 209 (2), 417-426. https://doi.org/10.1006/jcat.2002.3644

27. Trovarelli, A.; Boaro, M.; Rocchini, E.; de Leitenburg, C.; Dolcetti, G. Some recent developments in the characterization of ceria-based catalysts. J. Alloys Compd. 2001, 323-324, 584-591. https://doi.org/10.1016/S0925-8388(01)01181-1 
28. Crisafulli, C.; Scirè, S.; Minicò, S.; Solarino, L. Ni-Ru bimetallic catalysts for the $\mathrm{CO}_{2}$ reforming of methane. Appl. Catal. A 2002, 225 (1-2), 1-9. https://doi.org/10.1016/S0926$860 \times(01) 00585-3$

29. Valdés-Martínez, O. U.; Suárez-Toriello, V. A.; Reyes, J. A. d. I.; Pawelec, B.; Fierro, J. L. G. Support effect and metals interactions for $\mathrm{NiRu} / \mathrm{Al}_{2} \mathrm{O}_{3}, \mathrm{TiO}_{2}$ and $\mathrm{ZrO}_{2}$ catalysts in the hydrodeoxygenation of phenol. Catal. Today 2017, 296, 219-227. https://doi.org/10.1016/j.cattod.2017.04.007

30. Hwang, S.; Hong, U. G.; Lee, J.; Baik, J. H.; Koh, D. J.; Lim, H.; Song, I. K. Methanation of Carbon Dioxide Over Mesoporous Nickel-M-Alumina ( $\mathrm{M}=\mathrm{Fe}, \mathrm{Zr}, \mathrm{Ni}, \mathrm{Y}$, and $\mathrm{Mg}$ ) Xerogel Catalysts: Effect of Second Metal. Catal. Lett. 2012, 142 (7), 860-868. https://doi.org/10.1007/s10562-012-0842-0

31. Pandey, D.; Deo, G. Effect of support on the catalytic activity of supported Ni-Fe catalysts for the $\mathrm{CO}_{2}$ methanation reaction. J. Ind. Eng. Chem. 2016, 33, 99-107. https://doi.org/10.1016/j.jiec.2015.09.019

32. Pastor-Pérez, L.; Patel, V.; Le Saché, E.; Reina, T. R. $\mathrm{CO}_{2}$ methanation in the presence of methane: Catalysts design and effect of methane concentration in the reaction mixture. Journal of the Energy Institute 2020, 93 (1), 415-424. https://doi.org/10.1016/j.joei.2019.01.015

33. Álvarez, A.; Bobadilla, L. F.; Garcilaso, V.; Centeno, M. A.; Odriozola, J. A. $\mathrm{CO}_{2}$ reforming of methane over Ni-Ru supported catalysts: On the nature of active sites by operando DRIFTS study. J. CO2 Util. 2018, 24, 509-515. https://doi.org/10.1016/j.jcou.2018.01.027

34. Winter, L. R.; Gomez, E.; Yan, B.; Yao, S.; Chen, J. G. Tuning Ni-catalyzed $\mathrm{CO}_{2}$ hydrogenation selectivity via $\mathrm{Ni}$-ceria support interactions and $\mathrm{Ni}$-Fe bimetallic formation. Appl. Catal. B 2018, 224, 442-450. https://doi.org/10.1016/j.apcatb.2017.10.036

35. Zhu, L.; Shan, S.; Petkov, V.; Hu, W.; Kroner, A.; Zheng, J.; Yu, C.; Zhang, N.; Li, Y.; Luque, R.; Zhong, C.-J.; Ye, H.; Yang, Z.; Chen, B. H. Ruthenium-nickel-nickel hydroxide nanoparticles for room temperature catalytic hydrogenation. J. Mater. Chem. A 2017, 5 (17), 7869-7875. https://doi.org/10.1039/C7TA01437F

36. Ko, J.; Kim, B.-K.; Han, J. W. Density Functional Theory Study for Catalytic Activation and Dissociation of $\mathrm{CO}_{2}$ on Bimetallic Alloy Surfaces. J. Phys. Chem. C 2016, 120 (6), 3438-3447. https://doi.org/10.1021/acs.jpcc.6b00221

37. Quindimil, A.; De-La-Torre, U.; Pereda-Ayo, B.; Davó-Quiñonero, A.; Bailón-García, E.; Lozano-Castelló, D.; González-Marcos, J. A.; Bueno-López, A.; González-Velasco, J. R. Effect of metal loading on the $\mathrm{CO}_{2}$ methanation: A comparison between alumina supported $\mathrm{Ni}$ and $\mathrm{Ru}$ catalysts. Catal. Today 2019, in press. https://doi.org/10.1016/j.cattod.2019.06.027

38. Yang, L.; Pastor-Pérez, L.; Villora-Pico, J. J.; Gu, S.; Sepúlveda-Escribano, A.; Reina, T. R. $\mathrm{CO}_{2}$ valorisation via reverse water-gas shift reaction using promoted $\mathrm{Fe} / \mathrm{CeO}_{2}-\mathrm{Al}_{2} \mathrm{O}_{3}$ catalysts: Showcasing the potential of advanced catalysts to explore new processes design. Appl. Catal. A 2020, 593, 117442. https://doi.org/10.1016/j.apcata.2020.117442

39. Tada, S.; Shimizu, T.; Kameyama, H.; Haneda, T.; Kikuchi, R. Ni/CeO $\mathrm{Cl}_{2}$ catalysts with high $\mathrm{CO}_{2}$ methanation activity and high $\mathrm{CH}_{4}$ selectivity at low temperatures. Int. J. Hydrogen Energy 2012, 37 (7), 5527-5531. https://doi.org/10.1016/j.ijhydene.2011.12.122

40. Andriopoulou, C.; Trimpalis, A.; Petallidou, K. C.; Sgoura, A.; Efstathiou, A. M.; Boghosian, S. Structural and Redox Properties of $\mathrm{Ce}_{1-x} \mathrm{Zr}_{x} \mathrm{O}_{2-\delta}$ and $\mathrm{Ce}_{0.8} \mathrm{Zr}_{0.15} \mathrm{RE}_{0.05} \mathrm{O}_{2-\delta}(\mathrm{RE}: \mathrm{La}, \mathrm{Nd}, \mathrm{Pr}, \mathrm{Y})$ Solids 
Studied by High Temperature in Situ Raman Spectroscopy. J. Phys. Chem. C 2017, 121 (14), 79317943. https://doi.org/10.1021/acs.jpcc.7b00515 
For Table of Contents Use Only:

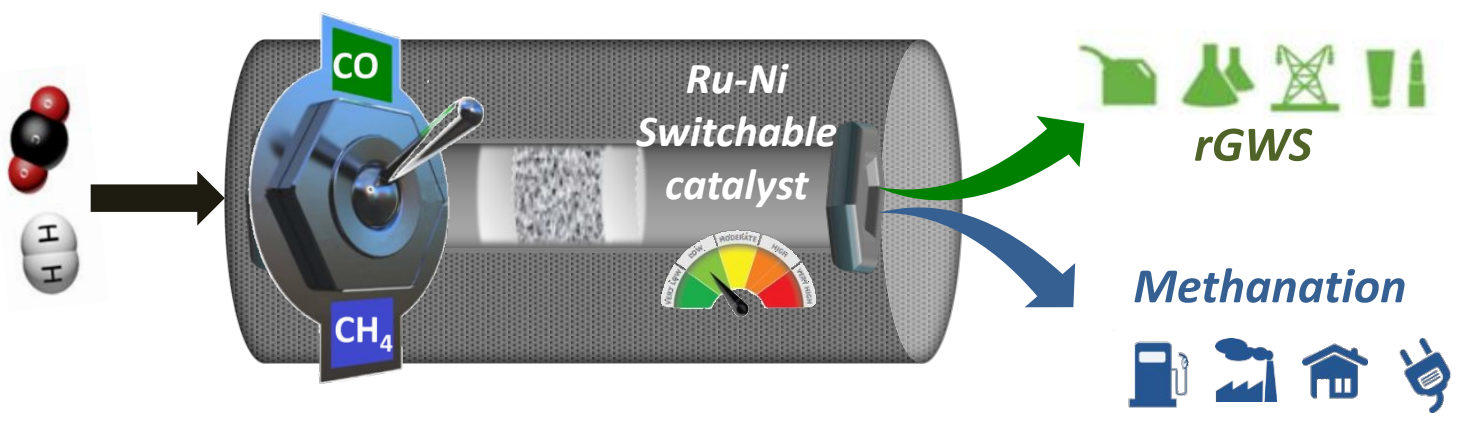

A dual catalyst is reported to upgrade $\mathrm{CO}_{2}$ emissions to synthetic natural gas and syngas. 